\title{
Delegitimation of Single-Mux Policy on Re-Regulation Process of Indonesian Broadcasting Bill in Media Framing
}

\author{
ABDUL FADLI KALALOI \\ Telkom University, Indonesia
}

\begin{abstract}
This study aims to explain the reality behind the framing of negative coverage of the single-mux policy in the re-regulation of Law No.32/2002, from a more macro perspective. Framing negative news by building reader cynicism on the single-mux policy option is associated as one of the efforts to delegitimize the single-mux policy, throughout the process of discussing the policy in Parliament. This research links the reality between negative news framing around single-mux policy options, with the media agenda in the broadcast industry in Indonesia. The author used the concept of framing-strategy analysis Cappella and Jamieson (1997) as an analysis tool, to analyze data from detikcom content as online news media around the debate on single-mux and multi-mux policies on 2017-2018 reporting period. The results identified that the media developed a negative narrative about single-mux policies aimed to rise public cynicism about the policy. Cynicism is built by constructing issues around singlemux policies with policy impacts that conflict with democratic values, such as mass layoffs in the broadcasting industry, the issue of excesses of authoritarian policies because management rights are controlled solely by the government, to the issue of unpreparedness of government infrastructure which results in a waste of budget in the process of procuring new infrastructure. These facts the author associates with the effort to delegitimize single-mux policy options in the legislation process, using the arguments of Berger, Ridgeway, Fisek and Norman, (1998).
\end{abstract}

Keywords: Framing analysis, broadcasting policy, framing-strategy, value framing, delegitimation.

\section{INTRODUCTION}

Since over three decades ago, broadcasting has been seen as pervasive as it is overtly affected by the development and innovations in the media and communication technology globally. Scholars have since been contemplating the effects that technology has on broadcasting in the aspects of policies and ownerships, a market economy, technocratic practices, media education, culture and even the environment (Jamaluddin, 2019). In the other side, to courage the Indonesian broadcasting management, in 2015, a re-regulation of Law No. $32 / 2002$ concerning broadcasting was proposed. In the draft profile data on page http://wikidpr.org, the process has lasted for 1802 days. This has become a new chapter in discussions related to an ideal broadcasting regulation, one of which is the right to manage broadcasting frequencies. Where in the draft Act, the regulations relating to the management rights of the broadcast frequency spectrum will directly impact the broadcast industry, both technically and business. Government discourse that will use a single-mux operator system, as announced on the official website of the Ministry of Communication and Information, dated June 7, 2017, received many responses from various associations engaged in the broadcast industry, one of them from the Indonesian Private Television Association (ATVSI), who expressed their criticism of the single-mux policy in various media reports. Single-mux is a form of frequency spectrum management, wherein, management policy is fully managed by the state as a single regulator, while the counter option is multi-mux, which is the policy option that was still in effect at the time of this research, following Law No. 32/2002, where 
Private broadcasting institutions are given legitimacy by the government to manage the broadcast frequency spectrum by themselves.

Examining the scarcity theory approach, the spectrum of electromagnetic waves (frequency) has a finite amount. This limitation is apparent from the number of applicants for frequency management licenses, but not all of them get spectrum allocation quota. Besides assuming the limited number of spectrums, the theory of scarcity also explains that the spectrum is a valuable resource. This value is related to economic value, that is, the spectrum can become a capitalist instrument to obtain material benefits, and also political value, wherein, the spectrum can function as a medium in spreading influence, and certain values to the wider community. Therefore, this spectrum should not be owned privately (personal) which is only directed to meet the interests of a particular person or group. This spectrum should be treated as a public resource owned by all members of the community. The state should be able to protect these resources and direct their management, for the greatest possible prosperity of the people (Rahayu et al., 2014, p.16). In the effort to propose a singlemux policy, the government's move was considered in line with the theory of scarcity itself, so that this reality eventually gave rise to different views between the government, as well as the broadcast industry association itself, in support of single-mux, and multi-policy options mux in the process of re-regulation of the Broadcasting Law. Media reporting is one way for the public to be involved and understand the development of the discussion of this regulation directly. However, in reality, media coverage tends not to be objective in presenting singlemux and multi-mux policy options in presenting the information. The media tends to only highlight single-policy policies mux as an undemocratic policy option. This is interesting and becomes the focus of this paper, single-mux policies that are in line with the theory of scarcity are framing as undemocratic policies in media coverage.

Contextually, the single-mux policy will harm the broadcast industry, where the frequency management rights that previously could be authorized to the private sector, became the sole authority by the government. This became the initial assumption as the reason for the birth of negative coverage of the single-mux policy in the media coverage. In terms of this, the writer defines as a form of delegitimation of single-mux policy, that is, when the normative perceptions have become separated or dissociated from, or irrelevant to the originally legitimate power and prestige order, we say that the power and prestige order has become delegitimated (Berger, Ridgeway, Fisek \& Norman, 1998, p.387). Therefore, the writer tries to analyze the news related to the single-mux and multi-mux policy debate, by asking research questions, namely, how the mass media delegitimates Single-mux policy, in the re-regulation agenda of Law No.32/2002 through the news? This is intended to describe the relationship between the media agenda and the re-regulation policy agenda of Law No. $32 / 2002$ which is currently under discussion, through mass media coverage.

\section{LITERATURE REVIEW}

In a democratic country, nothing new when looking at a public policy that is in the process of discussion then becomes the issue of public debate over the perception of information published by the mass media. This assumption was tested between 1995 and 2010 in the Netherlands and Sweden, on issues surrounding immigration reported in the newspaper. Parties who have an interest tend to disclose certain framing to be conveyed through the mass media, that is based on framing that best fits the policy agenda that fits their agenda, but also looks rational by parties who have the opposite view (van der Pas, 2013, p.2). Decker and Scholten's research in 2017, entitled "Framing the Immigration Policy Agenda: A 
Qualitative Comparative Analysis of Media Effects on Dutch Immigration Policies", they tried to analyze the effect that media framing has on the agenda of policy changes related to immigrants in the Netherlands. In his research Decker and Scholten (2017) focus on the quantity of media attention on immigrant issues, which are considered as the main influence in decision making.

Using the Qualitative Comparative Analysis method, the research found that the policy agenda becomes responsive when the agenda gets a high quantity of media attention and news framing that is critical of the policy, Dekker and Scholten (2017) also add that, in addition to being an important source of information related to issues policy issues, media coverage is also a medium that informs policymakers, about policy issues perceived by the public. With a qualitative comparative analysis method, Dekker and Scholten (2017) prioritize the quantity of news as an analytical material, in contrast to the framing analysis approach, which prioritizes the analysis of news framing contained in news content, which is intended to explain how news framing is displayed in research, intended to degrade a policy.

Other research that discusses the dualism of decision making in the policy agenda was written by Lee, Mcleod and Shah (2008) with the title "Framing Policy Debates: Dualism Issues, Journalistic Frames, and Opinion on Controversial Policy Issues". In this study, the authors find out how the impact of media reporting on public sympathy and debate in viewing policy options reported to the public, using the theory of value-framing analysis and framing strategy proposed by Cappella and Jamieson (1997). With a quantitative approach, the researchers conducted an experimental study of two models of news framing, namely concerning policies related to ethnicity and the second relating to immigration policy. They found that the emphasis on information alignments caused by framing the reporting strategy created a gap or void in the individual's cognitive decision-making process, which needed to be filled with alternative considerations (Lee, McLeod \& Shah, 2008, p.713). They also added that framing strategy, emphasizing partiality-based reasoning, the strategy framework encourages people to interpret partisan conflict as political play issues, where political action is determined by the motivation of certain parties, for personal or group political interests. From the results of these experiments, it was explained that their findings were consistent with Cappella and Jamieson (1997) and several other researchers (e.g., de Vreese \& Semetko, 2002; Valentino, 2001). Lee, McLeod, and Shah (2008) also state that their findings provide evidence that a journalistic framework can provide a clue about how policy conflicts are understood without the need to change opinions about the problem.

Research by Lee, McLeod and Shah (2008) become a reference in this study, in a different methodological approach, the authors use the same analytical instrument, which is looking at media coverage with the concept of framing-strategy analysis and framing-values proposed by Cappella and Jamieson (1997). Furthermore, the focus of this research highlights the news of the single-mux policy debate which gets information space that tends to be negative from various information in the mass media. Finally, the purpose of this study is to describe the media agenda in terms of framing negative coverage related to the single-mux policy option that the author assumes is a form of delegitimation. This research is considered important to provide understanding to the reader, related to how the mass media delegitimates a policy option, in the form of negative coverage. In the framing analysis approach, the use of Cappella and Jamieson (1997) framing analysis theory with valueframing instruments and framing-strategy. 


\section{METHODOLOGY}

This research was conducted with a descriptive qualitative method with a media content analysis approach and framing analysis techniques using Cappella and Jamieson's framing analysis theory (1997). The focus of this research is the news on the detik.com page, and the focus of the research is a discussion around news related to broadcasting frequency management policies. Detik.com is the first online news portal in Indonesia which is always consistent in the top five rankings of news portals in Indonesia with a site rate of $31 \%$. The choice of detik.com coverage as a sample in this study is based on the frequency of reporting which specifically addresses the broadcasting operator's mux system which is more than the discussion in several other media. Besides, in its position to preach information about mux operators, detik.com displays its position that is very partisan with almost all news in this context only highlighting the shortcomings of single-mux without any comparison with the multi-mux option.

Framing theory itself aims to identify the schemes used by individuals in looking at the world. Framing Theory helps us in reducing the complexity of information, also interpreting and constructing reality. Framing analysis theory is categorized as one of the important theories in media research discourse, journalism and political communication, especially in a democratic system where the media is one of the four pillars in a democratic society. Media researchers argue that framing theory is useful for analyzing inequality and power structures which mediates political issues (Littlejohn \& Foss, 2016, p.493). Framing theory in its concept can be explored from various perspectives, some of the conceptions expressed by some experts who describe framing theory in the form of conceptual analysis such as Pan and Kosicki (1993), Entman (1993), with Cappella and Jamieson (1997). In particular, the approach of framing analysis to experts has different units of analysis, therefore the use of analytical concepts in framing analysis theory must be adapted to the problem and context of the research itself. In this study, the author used the concept of Cappella and Jamieson (1997) in analyzing research data, the use of the concept of framing-strategy and value-framing adjusted for policy content in mass media reporting, as well as this approach used in the research of Lee, McLeod, and Shah, (2008) explained that strategy framing emphasizes partiality-based reasoning, the strategic framework encourages people to interpret partisan conflict as issues of political play, where political action is determined by the motivation of certain parties for personal or group political interests.

In the process of qualitative data analysis, according to Miles and Huberman (1992), it is divided into three stages, namely data reduction, data presentation, and concluding. Data reduction is the selection, concentration of attention as a simplification process in the process of reducing data related to research to be more specific. In the process, the writer selects news from various online media with the keyword "single-mux and multi-mux policy". So that found 136 news related to this policy from various online media in Indonesia with different backgrounds (heterogeneous). Simplification is then performed by selecting news media based on the intensity and variety of news coverage, including news content and subject matter in the news content, to focus research data to be homogeneous. As a result, the author chose news from the Detik.com website as a sample that was deemed to have met the qualifications in terms of variations in reporting and subjects in varied news content. From the detik.com page, the writer collected 31 news that specifically discussed the frequency management rights in the re-regulation process of Law No.32/2002. Searching the detik.com news portal in the 2017-2018 timeframe, the author found 14 news with multi mux keywords 
and 17 news with single-mux keywords, which will then be presented in the data analysis process.

In addition to primary data, secondary data is also used as a comparison to look at the news objectively by displaying data sourced from parliamentary statements and several minutes of meeting minutes to be reviewed as a medium to see the objectivity of media coverage in this study. Secondary data in this study were obtained from the page https://wikidpr.org which is also called JejakParlemen.id, which is a non-profit organization in the field of media and communication whose scope includes reportage, advocacy, and data inventory. This organization was formed in Jakarta in 2014 which was a community initiative in demanding more transparent performance of legislative members. The results of an inventory of data presented by JejakParlemen.id related to the development of the discussion on the re-regulation of the Broadcasting Law include information on the results of the meeting in the form of opinions expressed at meetings by parliamentarians and attendance of meeting participants are also presented on the page. In addition, secondary data are also sourced from information on the official length of the Indonesian Parliament $h t t p: / / d p r . g o . i d$ relating to the development of the discussion on the re-regulation of Law No.32/2002. All data in this study, both primary data and secondary data, were obtained by using the documentation technique from each official website page for which the source can be accounted for.

The data displayed will be analyzed using the value-framing approach and strategy framing, to see how media framing the news related to the single-mux policy itself, the narration produced by the media, then described with the strategy framing approach, to see what is highlighted in the news relating single-mux, and how the media narrate the policy in news framing. Furthermore, the author explains media framing objectively, by confirming secondary data, intending to strengthen the delegitimation argument itself.

\section{RESULT}

\section{Consolidation of Media Ownership and Indonesian Broadcasting Law Politics}

After the monetary crisis subsided, the country's economy improved, and Indonesia entered a post-reformation transition, where the interest of the authorities in establishing broadcasting institutions was very large. The euphoria of freedom of expression and the presence of broadcasting business opportunities led to the birth of many television broadcasting institutions. At the beginning of the reformation period in Indonesia, several new commercial televisions were established, including, Metro TV, Trans TV, Lativi, TV 7, and Global TV, and several local televisions spearheaded by the Jawa Pos group that spread across various regions. This phenomenon eventually gave rise to broad political-economic implications, where the process of business consolidation was ongoing and increasingly aggressive. This resulted in a concentration of ownership of commercial broadcasters. In research compiled by Rianto et al. (2014) stated that the initial consolidation was carried out with the aim of 'saving' existing businesses, but in subsequent developments, it was driven more by greed and capital accumulation as much as possible without considering a sense of justice and broad public interest.

The facts above are proven by the high level of acquisition of broadcasting companies after the reform. MNC group for example, not only took over RCTI but also acquired TPI and Global TV, it also expanded its business to the regional level as the Jawa Pos Group. The same thing was done by EMTEK by taking over SCTV and ANTV (Rianto et al., 2014). In the end, the 
consolidation in the broadcasting business gave rise to the emergence of a concentration of broadcast media ownership in the hands of a handful of parties (oligopoly). The reality in the consolidation of media ownership followed by this acquisition violates the provisions of the Broadcasting Law No. 32/2002 article 18 paragraph 1, which states that the ownership and control of a private broadcasting institution by one person or one legal entity, both in a broadcasting area and in several broadcasting areas, is restricted. This is also emphasized in Article 34 paragraph 4 of the Broadcasting Law, which states that the broadcasting permit is in the Take Over to other people. Not only that, but Government Regulation (PP No. 50 / 2005) concerning private broadcasting institutions (LPS) in article 32 paragraph 1 also emphasized that the concentration of ownership and control of Private Broadcasting Institutions (television broadcasting services) by one person or one legal entity, both in one broadcasting area, as well as in several regions throughout Indonesia are limited by stipulated conditions. Despite the legal facts, the consolidation of the owners of private broadcasting institutions continues without anyone being able to withstand this, which according to media researchers is related to weak implementation of the law (Rianto et al., 2014).

By encouraging the single-mux policy to be proposed as one of the policy options in the re-regulation of Law No.32/2002, the government has tried to initiate significant changes in broadcasting regulations in Indonesia. The 20 years after the reform did not change much in the broadcasting system in Indonesia. Liberalization of the broadcasting policy forced the ownership system in the broadcast industry to be owned by socially, politically and economically powerful actors, so that this condition gave rise to an oligopoly form of media ownership in Indonesia.

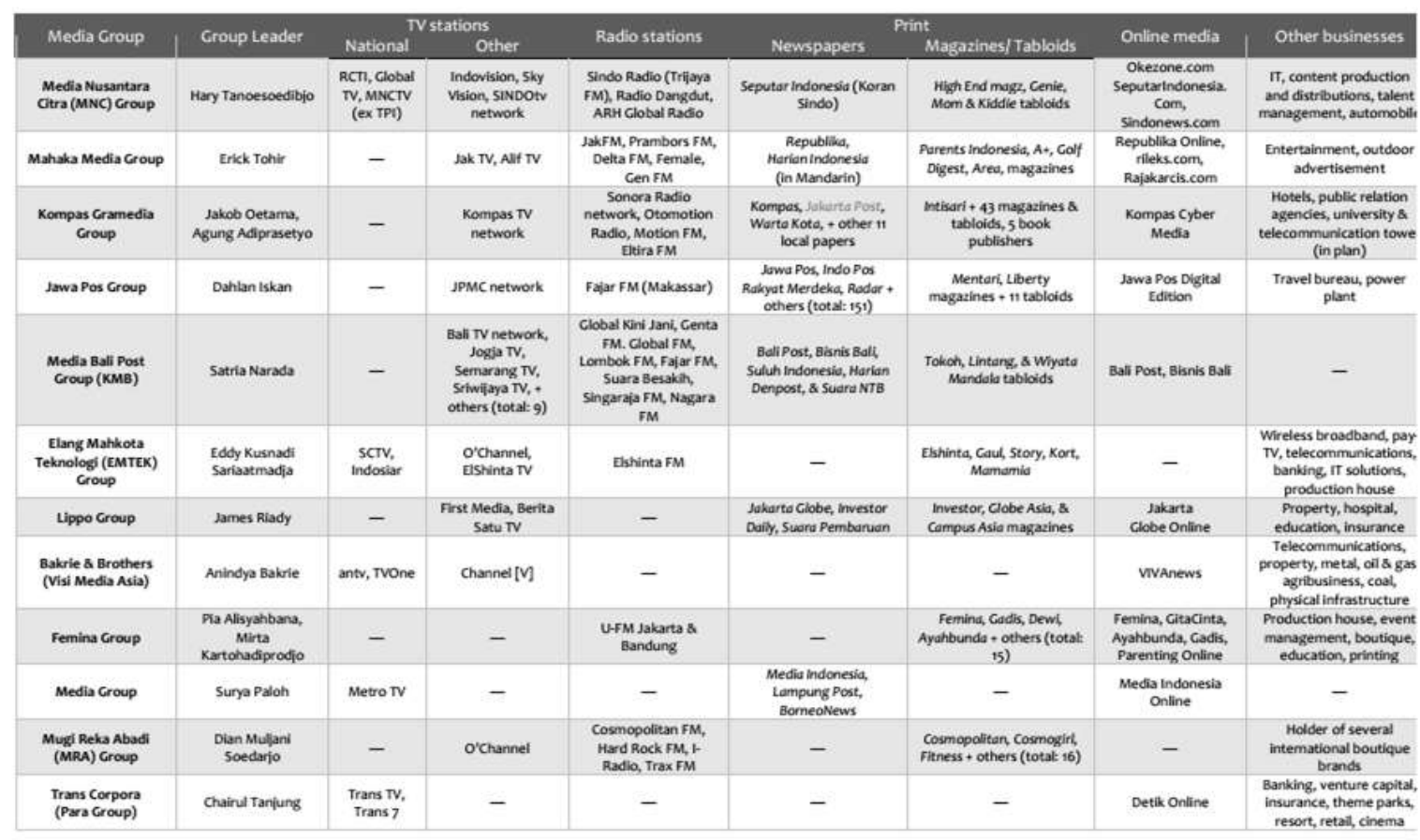

Figure 1: Map of Oligopoly Ownership of Broadcast Media in Indonesia Source: Lim (2012). The League of Thirteen.

This ownership network is rooted in the broadcast industry, print media, and online media. For example, detik.com as an online media owned by Trans Corpora also has several television stations. Kompas.com which is owned by Kompas Gramedia Group also has a 
Kompas TV television station, besides that Liputan6.com which is owned by EMTEK also has several television stations, such as SCTV and ANTV, as well as several other media companies that also have a network of ownership of mass media and broadcast media.

The relationship in the media ownership network, as well as the power over violations of legal norms freely as the fact that the author has explained before, seems to look like a privilege owned by a giant media company in Indonesia. This fact, is one of the basic arguments for the assumptions built in this study, that the concept of single-mux can be a policy option that harms media companies, especially if frequency management is distributed proportionally, which automatically contradicts the form of oligopoly business schemes the media in Indonesia so that the author's view which states that negative reporting on the single-mux policy option is a form of delegitimation of the single-mux policy as a reality that can be understood in general. The conclusion is, negative coverage in single-mux policy framing, cannot be separated from the reality of media ownership networks that have personal interests in the process of re-regulation of the management of the broadcast frequency spectrum itself, as Karl Marx expresses, that the media are the governing class, the media are ideological tools that perpetuate the dominance of the capitalist class against the public who are treated solely as consumers, and against the owner of power to smooth the birth of pro-market regulations (Sudibyo, 2004).

Strategy-framing, Value-Framing and the Delegitimation of Single-mux Policy in Media Coverage

Cappella and Jamieson (1997) argue that framing-strategy packaging includes information about manoeuvers and tactics from a political perspective, also about problems and solutions. So, this makes it possible for readers of news that is packed with framing-strategies to reverse the substance as well as information strategies that emphasize game orientation in reportage politics. While framing issues, emphasizing problems and possible solutions, involvement with opposing alternative views, and critical analysis and reformulation, advocacy, and compromise if needed (Cappella \& Jamieson, 1997, p.110).

The framing-strategy and value-framing approach used in analyzing media news framing related to single-mux policy is based on the massive findings of negative news that reviews the policy options. The author sees the news packaging as a form of cynicism about the single-mux policy option. For example, when we type the keyword Single-mux operator in the google search engine, there are 546,000 results as follows: 


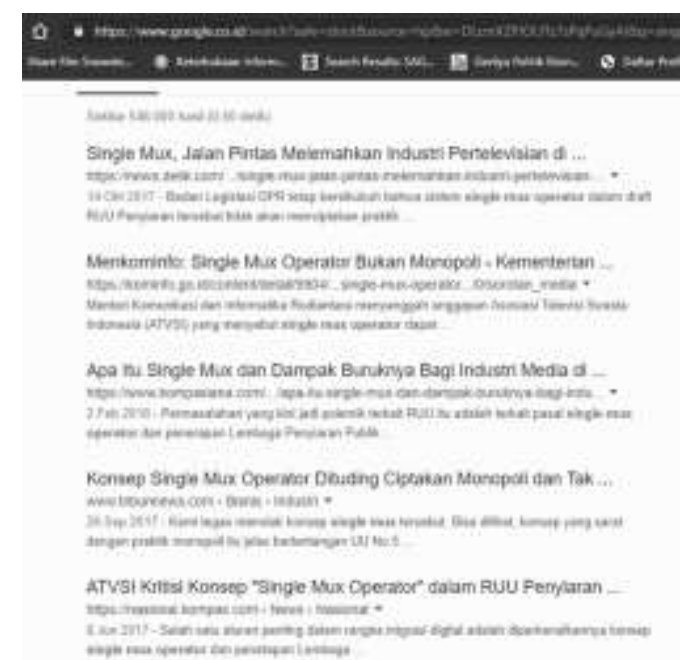

Figure 2: Display of Google Search with Single-mux Keywords

The majority of the reports that appear in the first slide, all of which feature titles that state the negative impact of the single-mux policy option, ranging from "weakening the television industry" to "creating a monopoly". Framing negative coverage of the single-mux policy option, depicted in a media package that tries to distance the theory of scarcity, or the concept of democratization of ideal broadcasting policy, with the single-mux concept itself, by 'selling' cynicism in the form of the negative impact of a single-mux policy. In the concept of Berger's delegitimacy, Berger, Ridgeway, Fisek and Norman, (1998) revealed, when the normative perceptions have become separated, or dissociated from or irrelevant the originally legitimate power and prestige order, we say that the power and prestige order have become delegitimated. Thus, framing news that tries to look at the ideal policy options with the perceptions described above, can be said as a form of delegitimation, which in this study, public policy is placed on options that are far from the ideal concept in media reporting.

Media frames provide boundaries around a news story and determine what is and are not newsworthy or notable. A-frame also refers to the way media as gatekeepers organise and present the ideas, events, and topics they cover. A single news story can be presented in multiple forms based on the perception, attitudes and preferences of the news source (Osama, Mohamed Oklah \& Mohd Faizal, 2020). In the concept of cover both sides, the media involves all stakeholders in reviewing the news, to be studied proportionally. In this case, among others, the government and the House of Representatives in their authority to make laws, as well as related parties that have a direct relationship with the law. So that information will then become a source of news, such as what, and how the framing is displayed, is a big part of the construction of reality itself.

For example, the news Detik.com 21 October 2017 with the title "Preparation of Broadcasting Bill Must Be Based on Justice": 


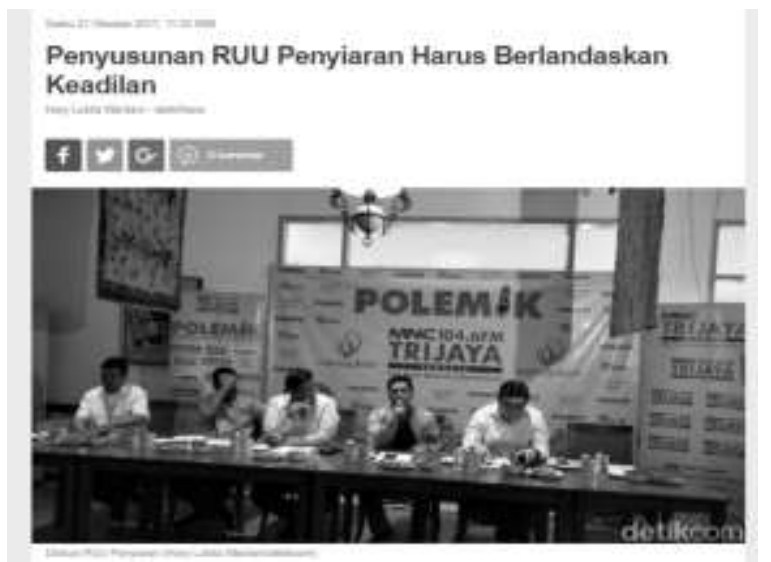

Figure 3: Detik.com News Source: Obtained from primary data

In the content, it is narrated that single-mux has the potential to present a monopoly in the broadcast industry. In the concept of value-framing, reporting usually describes a policy debate as a clash of moral principles or basic values, with disputing parties and conflicting based on a certain set of values. Here, detik.com tries to present information, that it is as if the single-mux policy violates the values of justice, intending to strengthen sympathy for the opposite policy (multi-mux). This information is packaged, only from one perspective, where other perspectives are not included in the framing of the news.

That, since October 3, 2017, in the Legislative Body's news, on the official website of the parliament http://www.dpr.go.id/, Chairman of the Legislative Body of the Republic of Indonesia Supratman Andi Agatas, dismissed the view that the concept of the single-mux operator in the draft bill Broadcasting will create monopolistic practices. Because, in the concept of single-mux, the frequency will be fully managed by the state.

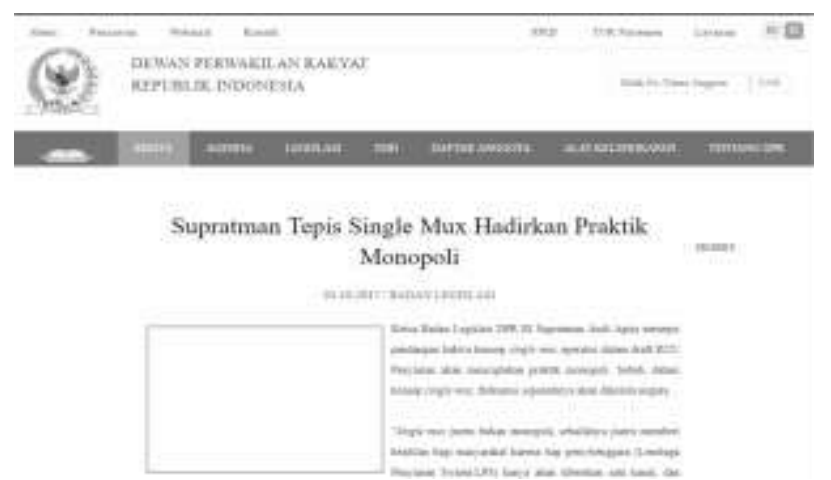

Figure 4: Information Release of Badan Legislasi DPR, October 3, 2017 Source: Obtained from secondary data

Supratman Said:

Single-mux is not a monopoly, on the contrary, it gives justice to the community because each organizer (Private Broadcasting Institution / LPS) will only be given one channel, and each channel contains 12 channels... 
Opinions like this, are not displayed by Detik.com, who certainly has enough resources to access the information. Thus, the author concludes that information related to the negative impact of single-mux is part of the framing-strategy carried out by detik.com in selecting information that does not support their views.

Sunaryo (in Rahayu et al., 2016, p. 62-63) revealed that one of the fundamental things in public policy is the regulatory criteria that should be ethical. At present, attention to economic interests is too dominant in underlying communication policies and regulations. Sunaryo revealed that the economy was too concerned with welfare issues (measured in gross domestic product or per capita income). If this is the only measurement, it will be dangerous because, in the name of economic maximization, public policymakers can sacrifice the freedom of others.

On the other hand, the media puts the single-mux policy option in an adverse perspective by selecting opinions that support the public interest more ideally. This can be seen in the news at October 21, 2017, with the title "Preparation of the Broadcasting Bill Must Be Based on Justice", as well as the news on September 25, 2017, with the title "Broadcasting Bill: The Concept of Single-Mux Operators Considered Not Democratic". Both of these stories explain single-mux as an unjust, potentially monopolistic, and undemocratic policy option, without including the opinion of related parties directly, for example, members of the DPR's Commission I, or other Independent Parties. While on the other hand, in a limited meeting with the agenda of listening to the response of the DPR Broadcasting Commission, which was held on March 21, 2017, Muhamad Misbakun from the Golongan Karya Party faction expressed his opinion as follows:

Broadcasting Bill, is very strategic for the DPR, where the civil democratic system is strengthened. According to that statement, the Broadcasting Bill is an initiation step and needs to be emphasized, that the frequency is public property and should not be broadcast content determined by market demand. Misbakhun stressed that frequency is the right of the state and in the Broadcasting Bill it must place the state in an important position, lest the state's presence is eliminated by its industry.

Misbakhun suggested that national TV should make its branches in the regions. The state must have state revenue in terms of frequency because so far the corporation has received trillions of income from the frequency, and the state does not get anything. Regarding the institution of dick, according to Misbakhun, it is very important and must be filled by competent people, because it is related to controlling content related to content and broadcast material. In reality, the current control institution has become repressive. Regarding broadcasts, Misbakhun was worried that certain broadcasts could not be raised because they discussed certain topics. Overall, according to the statement was conveyed by proposers from Commission 1 regarding the Broadcasting Bill, was already strong (wikidpr.org, 2017).

Misbakun's opinion puts the concept of frequency management in line with the theory of scarcity and supports the application of single-mux with an ideal argument. However, this opinion has no place in media coverage. Constellation in the process of policy discussion is a 
very important political process in policy-making, so if the media is located in the goal of fighting for the public interest, then the framing that is shown must be proportional.

Based on these findings, the author proves that there is a reality put forward by academics, as well as the legislature that has never been presented by detik.com in compiling its narrative related to the polemic of single-mux. So, it can be concluded that the reality displayed in detik.com news, is the result of the construction of information sourced from parties who have a common agenda with the media agenda. In its concept, framing-strategy regulate policy conflicts as conflicts of political interests and competitive strategies, usually, highlighting the political intrigues of competing parties, related to their goals, strategies, and tactics (Lee, McLeod \& Shah, 2008). The competition between single-mux and multi-mux policies in broadcast frequency management policies receives different attention from the media. Overall, the detik.com report only highlighted single-mux without a portion of the multi-mux discussion which was juxtaposed as a comparison in seeing the positive and negative impacts.

In the process of determining the policy agenda, the DPR, the Government and related parties are both a preference in the decision-making process. When the media reports information in a balanced presentation, it means that the media carries out its task in educating the public about the value of the policy agenda. Conversely, when information comes only from the preferences of one particular party, automatically selects information based on reporting needs. As an example:

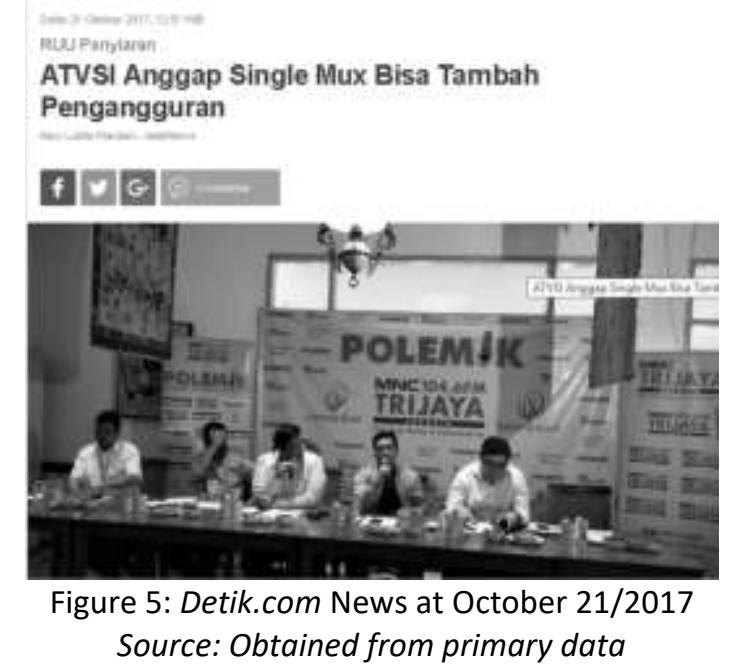

Using the Opinion of the Indonesian Private Television Association (ATVSI) in assessing the single-mux policy, in practice, ATVSI has interests that contradict the single-mux operator policy. As a related party that is part of the private broadcasting industry, ATVSI will reject the single-mux option. What's more, in its news content, ATVSI is the only source of information in the news, as a result, this information is only intended to discredit the single-mux policy. Similar to the following information: 


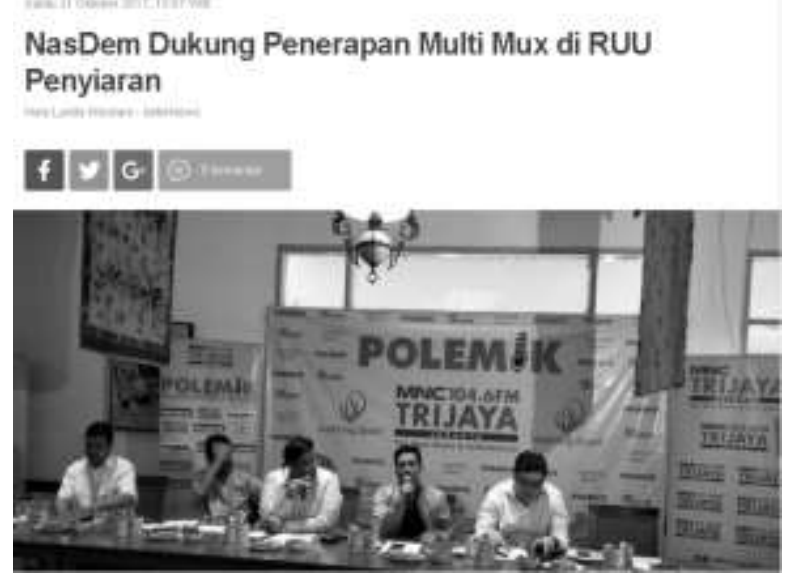

Figure 6: Detik.com News at Oktober 21/ 2017

Source: Obtained from primary data

The Nasional Demokrat Party (Nasdem) faction is part of the legislative party, however, in practice, the Nasdem party has links to the private broadcasting industry, where its general chairman, Surya Paloh, is one of the owners of Media Indonesia Group, one of the broadcasting companies that are directly interested with the policy agenda being discussed. The selection of subjects in the news content above actually originated from several related parties written in the detik.com to support of their arguments, unfortunately, they only use subjects that have the same interests and negate discussions related to the public interest.

Research on framing-strategy shows that media coverage activates public cynicism about the political process, and encourages distrust of government institutions and political leaders, and encourages political disarmament in some conditions. Whereas, framing values usually describe a policy debate as a clash of moral principles, or basic values, with disputing parties conflicting based on a certain set of values. What is at stake is, the legitimacy of one definition of morality or competence over another in the struggle to win or control resources (Lee, McLeod \& Shah, 2008). Both of these framing approaches, really proven to be used by detikcom in compiling the news analyzed in this study. The use of framing is used in several reports depending on the emphasis to be conveyed in the reporting. Lee, McLeod and Shah (2008) define that framing strategy leads to the strategic interpretation of candidates and political issues, while frame values, encourage individuals to interpret problems in moral or ethical terms.

The sample headlines above, all show the negative impact of single-mux. The information displayed, far from the form of public education or enlightenment related to the public policy agenda, detik.com does not present the conception of the two policy options equally, of course, this is a situation that is not ideal in the role of the media as an information channel. Instead of exposing the public to the advantages and disadvantages of the two policy options, the media tends to dissolve in transferring cynic information to the single-mux policy option, in this definition the author refers to as a form of delegitimation.

This situation is not new, in seeing framing as an effort to monopolize information that is the opposite. In her journal, Regina G. Lawrence (2000) presents a quantitative calculation of news trends with a framing strategy approach. In the results of this research, it is proven that there is a very strong correlation between the focus of reporting with public policy framing on a news agenda. Cappella and Jamieson (1997), divide it into three categories: the first is ISSUE, this category contains information about public policy issues, a substantial 
explanation from the legislative or government in viewing a policy issue. Second, is the GAME category, in this category contains political information that is part of the strategy-framing, explaining the implications, and the impact of implementation in a disproportionate political perspective. Third is MIXED, information that explains the relationship between the two equally in the portion of the news.

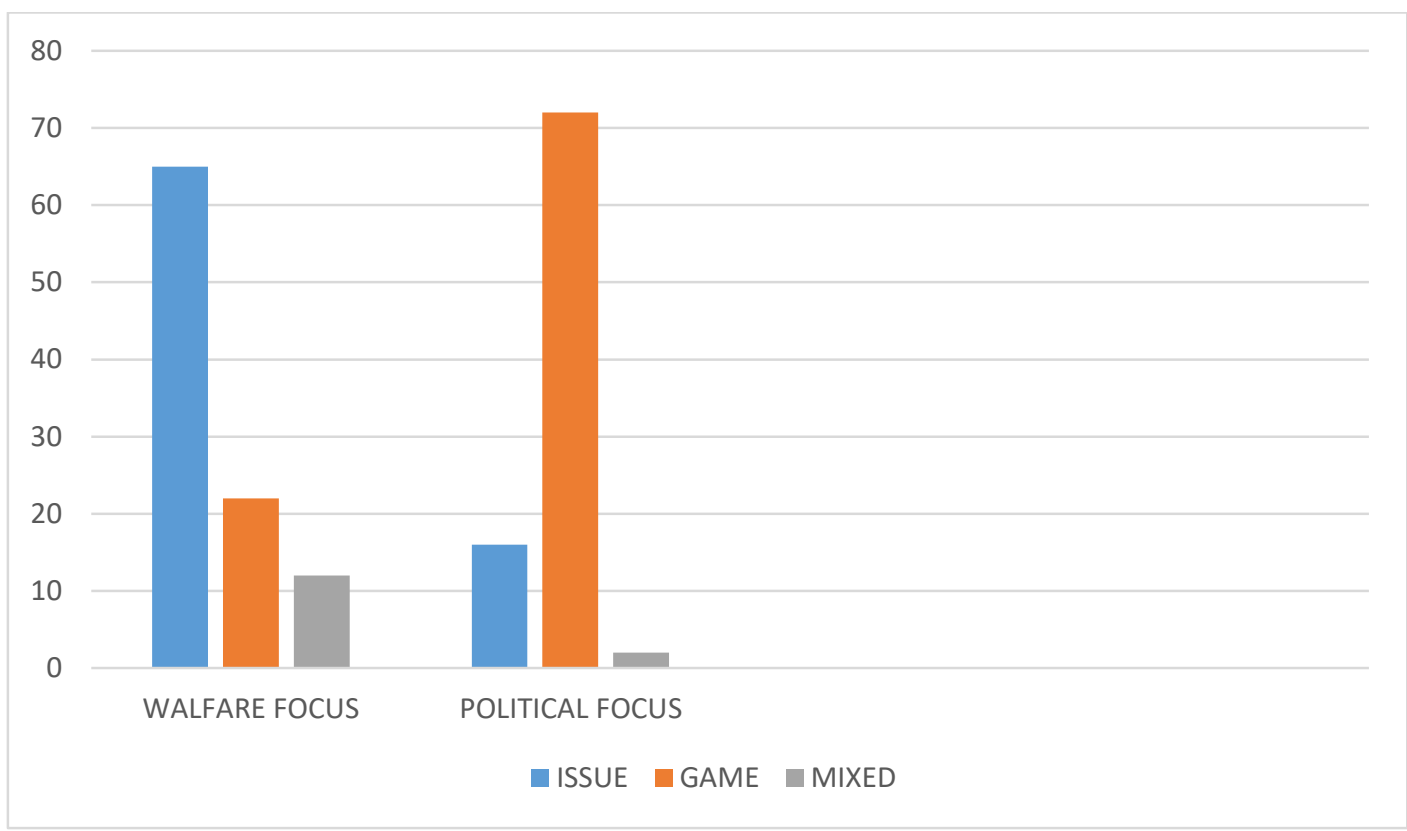

Figure 7: Framing Welfare Reform: Political Vs The Policy-Making Context Source: Regina G Lawrence, 2000 p. 102

The issue of substantial news related to the policy will always contradict information that is political or contains cynicism in public policy reporting. When information regarding welfare is focused on the frequency of information, automatically cynic reporting on a policy agenda will decrease dramatically. Conversely, when information that is cynical and in the form of strategy-framing increases frequency, then the information that contains about welfare in the public policy agenda, automatically decreases, this is what is meant by the struggle of substance in a piece of public information when the media is busy using sensational perspectives, then information which will substantially sink and vice versa.

This also happened in the case of discussing re-regulation of Law No. 32/2002, general information about single-mux policies was very few, most of the media only displayed negative values, so quantitatively the information discussing cynicism on the policy was very high. In contrast, the substance of the broadcasting policy, as well as the impact on society from this policy option, escapes the discussion of the media in disseminating its information to the public. In conclusion, the high negative frequency in reporting single-mux policy options cannot be separated from the media agenda in its importance to the re-regulation process of Law No.32/2002. 


\section{DISCUSSION}

The relationship between government and media policy is also seen as an important factor in how we define this complicated concept. Media policy cannot be placed in a vacuum environment since it operates in a political and historical context. In this sense, the government and its political power will always influence the media policy. In addition, the government also has the social responsibility to regulate and control the media industry to maintain the media market, media diversity, and also media quality that are necessary for the public good (Setianto, 2015). Wahyuni (2006, p.13) explains the weakness of the public broadcasting sector leads to the assumption to achieve a more democratic broadcasting system in Indonesia, the empowerment of public service broadcasting stations should remain a significant part of the media reform agenda. The dominations of private broadcasting in the public sphere, which is very important in a democratic system. The operation of commercial broadcasting stations, which prioritizes profit-making, threatens the social functions of television. Thesen $(2013$, p.6) states that negative framing occurs due to the weak position of policy options proposed by the opposition in the process of policymaking, so that the pattern of attacks carried out in the form of public information, by choosing news preferences that they will submit to show to the public about poor performance in policy options that are in opposition to their policy agenda.

In the concept proposed by Hänggli and Kriesi $(2012$, p.3), that to achieve the objectives of the media agenda requires strong information framing, where the framing displayed triggers a defensive reaction on the opposition or to the media audience, this has been proven in Chong and Druckman's (2007) research, that the relative strength of framing becomes the most important and very influential dimension on the media agenda. Such conditions are illustrated by Vliegenthart and Walgrave (2010, p.322), who reveals that setting agenda in political objectives is related to how the actors involved pay attention to a particular issue, the main claim is, political decisions require political attention and control shifts in public attention, is a condition for encouraging policy change. In this case, the pattern of changing attention is done by building information with negative framing on a single-mux policy.

In a theoretical view, there are three factors related to media coverage of policy issues that can contribute to changing views on the policy agenda. First is the quantity of media attention (Lawrence, 2000). This condition is very important for agenda-setting studies. The more media attention and the longer it lasts, the higher the likelihood of achieving the effect of setting a policy agenda (Baumgartner \& Jones, 1993). Second, the author considers the relationship between framing in media coverage and the problem framework on the policy agenda. When the majority of framing in media coverage is similar to the frame of the problem on the policy agenda, it is considered a "framing agreement". When the majority of framing in media coverage differs from the problem frame on the policy agenda, then the substance is about "frame contestation". In this case, media coverage is very important to the policy framework under discussion. Frame contestation was hypothesized to increase the likelihood of policy change (Boydstun et al., 2014, p.178). Third, the author studies whether framing problems in the media are consonant or dissonant (Walgrave \& van Aelst, 2006, p.88). The prevalence of frames in media coverage ranges from the dominance of one frame (frame consonance) to the existence of multiple frames given more or less the same attention (frame dissonance) (Entman, 2003, p.418), wherein consonant frames, an issue is consistently published in a media institution, this answers the position of the issues surrounding the 
Single-mux policy in consonant reporting, which in all traces of reporting are only displayed in one condition, namely policies that have a negative impact.

Walgrave and van Aelst (2011 p. 303) are of the view that, when individual media is not so influential, mass media is an extraordinary force "when the consonant scope is across the media, and when the mass media is in a 'pressure mode' it is understood that media coverage for a case is more likely to be associated with policy changes when media coverage is characterized by a consonant frame. When various media report the same problem in a single framing for a relatively long time, media coverage is more likely to influence policy decisions (Eilders, 2000, in Walgrave \& van Aelst, 2006). The opinion above accommodates similar circumstances in this study, the author agrees that when the media institution is in a condition where a policy option will have an impact on the frequency ownership system, then the consonant framing feature has been proven in this study, the pattern described in This conceptual then reinforces hi the thesis on efforts to change the policy agenda through the news that alienates a policy option by reporting. Imagine a situation in which the power and prestige order has become legitimate, and when events occur that make the order of performance expectation incongruent with that initial order. The existence of such an incongruence undermines the normative prescriptions that have been applied to the power and prestige order, and this creates the possibility that the legitimate order will become delegitimated (Berger, Ridgeway, Fisek \& Norman, 1998, p.387). The conditions above are a reality that also occurs in discussions related to reporting single-mux policy options. There are so many concepts that encourage broadcast democratization by seeking dedication to media ownership, but on the contrary, the news is revealed that it is not democratic.

The policy agenda only becomes responsive when media framing is dominated by the current policy frame contest. The analysis shows the causal mechanism of democratic legitimacy, which is different from the influence of the media on the political agenda. Apart from being an important source of information on policy issues, media coverage informs policymakers about how policy issues are felt by the public. Media coverage is shaped by and formative public opinion (Dekker \& Scholten, 2017). Policymakers tend to be responsive to media coverage because they are considered as the representation of public opinion (Walgrave \& van Aelst, 2006). When a frame in media coverage that is considered a representation of public opinion competes with the current policy framework, it forces the policy agenda to respond.

\section{CONCLUSION}

Based on the results of this study, the author concludes that negative coverage framing the strategy-framing and value-framing approach is aimed at creating cynicism in single-mux policy options and presenting empathy for multi-mux policies indirectly. Walgrave and van Aelst (2006) revealed that this could occur due to the condition of media institutions that are in a 'pressure mode'. The single-mux policy can indirectly harm the broadcast industry business in an oligopoly format, where the mass media in Indonesia are part of an ownership network in one group on cross-platform ownership. That is the effort to delegitimize singlemux policy is a real fact, which is carried out by suppressing single-mux policy options with negative coverage, to prevent agenda-setting of single-mux policy options, or in the language of Berger, Ridgeway, Fisek and Norman (1998) When the normative perceptions have separated or dissociated from or irrelevant the originally legitimated power and prestige order, we say that the power and prestige order has become delegitimated. 
Finally, this study concludes that the consideration of the impact of the single-mux policy changes the management system and ownership of the frequency spectrum. This condition indirectly places the position of oligopolistic media companies in Indonesia under pressure, so that in the reporting process around this policy issue, the mass media are in a network structure of media ownership, have had a personal purposive agenda in compiling news information, by building reality to delegitimize single-mux operator policy options through news framing. The results of this study identify, detik.com builds a negative narrative in the Single-mux reporting aimed to give rise to public cynicism. They conducted single-mux policies would have impacted to mass layoffs (unemployment) in the broadcasting industry, the issue of excesses of authoritarian policies because of the management rights that are controlled solely by the government, to the issue of unpreparedness government infrastructure that results in budget wastage in the process of procuring new infrastructure. Conceptually this is referred by Cappella and Jamieson (1997) as framing-strategy, in compiling the negative narrative, gathering information that is following the needs of media institutions, by accommodating the opinions of various the party who has conceptual legitimacy and experience in the broadcast industry but eliminates opposing opinions. Furthermore, to influence the agenda-setting process, the media constructs issues around single-mux policies with policy impacts that conflict with democratic values to delegitimize single-mux policies in the legislative process. This is constructed in a news narrative, citing expert opinions from a legal expert background, but without confirmation from other parties. The facts in this study are written conceptually as stated in the discussion points. Shows how the media delegitimated the single-mux policy in the discussion of Law no. 32/2002.

BIODATA

Abdul Fadli Kalaloi is a junior lecturer at Telkom University, Indonesia. His research interest is on media and communication policy, media and cultural studies and media digital society. Email: fadkalaloi@telkomuniversity.ac.id 


\section{REFERENCES}

Baumgartner, F. R., \& Jones, B. D. (1993). Agendas and instability in American politics. Chicago: The University of Chicago Press.

Berger, J., Ridgeway, C. L., Fisek, M. H., \& Norman, R. Z. (1998). Prestige, the legitimation and delegitimation of power and order. American Sociological Review, 63(3), 379405. Retrieved from http://www.jstor.org/stable/2657555

Boydstun, A. E., Bevan, S., \& Thomas III, H. F. (2014). The importance of attention diversity and how to measure it. Policy Studies Journal, 42(2), 173-196. Retrieved from http://www.amber-

boydstun.com/uploads/1/0/6/5/106535199/aboydstun2014_the_importance_of_at tention_diversity_and_how_to_measure_it.pdf

Cappella, J. N., \& Jamieson, K. H. (1997). Spiral of cynicism: The press and public good. New York: Oxford University Press.

Chong, D., \& Druckman, J. N. (2007). A theory of framing and opinion formation in competitive elite environments. Journal of Communication, 57(1), 99-118. https://doi.org/10.1111/j.1460-2466.2006.00331.x

Dekker, R., \& Scholten, P. (2017). Framing the immigration policy agenda: A qualitative comparative analysis of media effects on Dutch immigration policies. The International Journal of Press/Politics, 22(2), 202-222. https://doi.org/10.1177/1940161216688323

de Vreese, C. H., \& Semetko, H. A. (2002). Cynical and engaged: Strategic campaign coverage, public opinion, and mobilization in a referendum. Communication Research, 29(6), 615-641. https://doi.org/10.1177/009365002237829

Entman, R. M. (1993). Framing: Toward clarification of a fractured paradigm. Journal of Communication, 43(4), 51-58.

Entman, R. M. (2003). Projections of power: Framing news, public opinion and US foreign policy. Chicago: University of Chicago Press.

Hänggli, R., \& Kriesi, H. (2012). Frame construction and frame promotion (Strategic framing choices). American Behavioral Scientist, 56(3), 260-278. https://doi.org/10.1177/0002764211426325

Jamaluddin Aziz. (2019). Retrieving trends and issues of penyiaran/broadcasting in Malaysian parliamentary debates from 1957 to 2018: A culturomics approach. Jurnal Komunikasi: Malaysian Journal of Communication, 35(4), 172-192. https://doi.org/10.17576/JKMJC-2019-3504-11

Lawrence, R. G. (2000). Game framing issue: Tracking the strategy frame in public policy news. Political Communication, 17(2), 93-114. https://doi.org/10.1080/105846000198422

Lee, N.-J., McLeod, D. M., \& Shah, D. V. (2008). Framing policy debates: Issue dualism, journalistic frames, and opinions on controversial policy issues. Communication Research, 35(5), 695-718. https://doi.org/10.1177/0093650208321792

Lim, M. (2012). The league of thirteen: Media concentration in Indonesia. Participatory Media Lab by Arizona State University and Ford Foundation, 2. Retrieved from http://www.public.asu.edu/ mlim4/files/Lim_IndoMediaOwnership_2012

Littlejohn, S. W. (2009). Encyclopedia of communication theory. US: Sage Publication.

Miles, M. B., \& Huberman, A. M. (1994). Qualitative data analysis. Thousand Oak: SAGE. 
Osama Kanaker, Mohamed Oklah Abughazlih, \& Mohd Faizal Kasmani. (2020). Media framing of minorities' crisis: A study on Aljazeera and BBC News coverage of the Rohingya. Jurnal Komunikasi: Malaysian Journal of Communication, 36(2), 1-16. https://doi.org/10.17576/JKMJC-2020-3602-01

Pan, Z., \& Kosicki, G. M. (1993). Framing analysis: An approach to news discourse. Political Communication, 10(1), 55-75. https://doi.org/10.1080/10584609.1993.9962963

Rahayu, Wahyono, B., Wendratama, E., Yusuf, I. A., Kurnia, N., Rianto, P., Adiputra, W. M., \& Siregar, A. E. (2016). Membangun sistem komunikasi Indonesia: Terintegrasi, adaptif, dan demokratis. Yogyakarta: Pr2Media dan Yayasan Tifa.

Rianto, P., Rahayu, Yusuf, I. A., Wahyono, B., Zuhri, S., Cahyono, M. F., \& Siregar, A. E. (2014). Kepemilikan dan intervesi siaran: Perampasan hak publik, dominasi dan bahaya media ditangan segelintir orang. Yogyakarta: PR2Media.

Setianto, Y. P. (2015). Media policy in the context of global media flows, the internet, and piracy: An historical analysis of media regulation in Indonesia. Jurnal Komunikasi: Malaysian Journal of Communication, 31(2), 371-388.

Shah, D. V., Domke, D., \& Wackman, D. B. (2008). The effects of value-framing on political judgment and reasoning. In S. D. Reese, O. H. Gandy, Jr., \& A. E. Grant (Eds.), Framing public life: Perspectives on media and our understanding of the social world (p. 227). London: Lawrence Erlbaum Associates, Publishers.

Sudibyo, A. (2004). Ekonomi politik medai penyiaran. Yogyakarta: ISAI.

Thesen, G. (2013). When good news is scarce and bad news is good: Government responsibilities and opposition possibilities in political agenda-setting. European Journal of Political Research, 52 (364-389). https://doi.org/10.1111/j.14756765.2012.02075.x

Top-Site. (2020, April Saturday). Indonesian news media top site rank. Alexa.com. Retrieved from https://www.alexa.com/siteinfo/detik.com

Valentino, N. A., Beckmann, M. N., \& Buhr, T. A. (2001). A spiral of cynicism for some: The contingent effects of campaign news frames on participation and confidence in government. Political Communication, 18(4), 347-367. https://doi.org/10.1080/10584600152647083

van Aelst, P., \& Walgrave, S. (2011). Minimal of massive? The political agenda setting power of the mass media according to different methods. The International Journal of Press/Politics, 295-313.

van der Pas, D. (2013). Making hay while the sun shines: Do parties only respond to media attention when the framing is right? The International Journal of Press/Politics, 19(1), 42-65. https://www.doi.org/10.1177/1940161213508207

Vliegenthart, R., \& Walgrave, S. (2010). When media matter for politics: Partisan moderators of mass media influence on parliament in Belgium, 1993-2000. Party Politics, 17(3), 321-342. 322. https://doi.org/10.1177/1354068810366016

Wahyuni, H. I. (2006). Indonesia broadcasting policy: The limits of re-regulations to creat a democratic broadcasting system. In N. Prajanto (Ed.), Media komunikasi: Siapa mengorbankan siapa (pp. 13-19). Yogyakarta: Fisipol UGM.

Walgrave, S., \& van Aelst, P. (2006). The contingency of the mass media's political agenda setting power: Toward a preliminary theory. Journal of Communication, 56(1), 88109. https://doi.org/10.1111/j.1460-2466.2006.00005.x 